\title{
Amor e conhecimento: Freud e Espinosa
}

\author{
Marcos Ferreira de Paula ${ }^{1}$
}

Resumo: Neste artigo, elabora-se uma reflexão sobre a relação entre amor e conhecimento em Freud e Espinosa, tomando-se como núcleo da análise as teses de Freud, em seu famoso ensaio sobre Leonardo da Vinci. Busca-se mostrar que a oposiçāo freudiana entre amor e conhecimento, a qual se deixa captar no conceito de sublimação, mas não tem lugar no pensamento de Espinosa. Na teoria espinosana dos afetos, tal oposição se desfaz; e é sobretudo através do conceito de Amor Dei Intellectuallis, apresentado na Parte V de sua Ética, que Espinosa deixa ver que, em vez de oposição, há antes a realização plena do amor enquanto ação da mente que conhece a si no seio da Natureza imanente.

Palavras-chave: Freud. Amor. Conhecimento. Espinosa. Sublimaçáo.

para Márcio Policastro

Por toda a minha vida, eu testemunhei, tanto a respeito da pessoa quanto da obra de pensamento do grande filósofo Espinosa, uma estima excepcional, embora pouco intimidada.

FREUD, em carta a Siegfried Hessing, 9 de julho de1932.

E assim, porque a Mente goza deste Amor divino ou felicidade, ela tem o poder de coibir a lascivia. E como a potência humana para coibir os afetos consiste no só intelecto, logo ninguém goza da felicidade porque coibiu os afetos, mas, ao contrário, o poder de coibir a lascivia origina-se da própria felicidade.

ESPINOSA, Ética, Parte V, prop. 42, dem.

1 Professor de Filosofia do curso de Serviço Social da Universidade Federal de São Paulo (UNIFESP), Santos, SP - Brasil. (D) https://orcid.org/0000-0002-9510-9046. E-mail: marcos.paula@unifesp.br.

https://doi.org/10.1590/0101-3173.2021.v44n4.24.p291

This is an open-access article distributed under the terms of the Creative Commons Attribution License. 


\section{INTRODUÇÃo}

Dentre os correspondentes de Freud, houve um certo Lothar Bickel, um médico e filósofo que escreveu sobre Kant, Espinosa e o próprio Freud. No ano de 1931, pensando em redigir um volume sobre Espinosa, Bickel enviou uma carta a Freud, pedindo sua opiniấo a respeito do filósofo. No dia 28 de junho daquele ano, Freud respondeu:

Admito de boa vontade a minha dívida para com Spinoza. Não cheguei a citar diretamente seu nome porque não retirei meus pressupostos de sua obra, e sim da atmosfera criada por ele. E porque não havia em absoluto a necessidade de uma legitimação filosófica. (FREUD apud SOUZA, 1990, p. 219).

Qual era exatamente a dívida do pai da psicanálise em relação ao autor da Ética? Provavelmente, ela náo se encontra no inovador e subversivo conceito de Deus. Freud era suficientemente avesso às metafísicas para aceitar o deus de Espinosa, ainda que se tratasse de um deus impessoal e identificado à Natureza - Deus sive Natura -, um deus cujo conceito, se bem compreendido, implica que aquele que o ame não possa exigir ser amado por ele (ESPINOSA, 2015a, p. 547); um deus que não é pai, protetor, caprichoso, que distribui castigos e recompensas etc. (ESPINOSA, 2015a, p. 109-121).

É possível que Freud interpretasse a ideia de Deus, em Espinosa, como uma alternativa às elaboraçóes do Deus pai pessoal, resultante do "complexo de pai” que tem lugar na infância. A única diferença seria que, no lugar de um Deus-pai, representante da autoridade, Espinosa teria concebido a ideia de uma Natureza-mãe, mais gentil, generosa e acolhedora. ${ }^{2}$ Nos dois os casos, as concepções metafísicas, filosóficas ou religiosas resultariam da expressão adulta de complexos infantis. Certamente seria uma simplificação grosseira da Parte I da Ética conceber o deus de Espinosa como substituto sublimado da figura do pai, mas Freud, se dispusesse de material psicanalítico sobre a formaçáo psíquica do filósofo, poderia talvez elencar muitos motivos de ordem psicológica para sustentar sua interpretação.

${ }^{2}$ Em O futuro de uma ilusão, Freud considera que o núcleo por trás de toda "figura divina" é sempre o pai. Referindo-se ao monoteísmo judaico, ele escreve: "O povo que primeiramente realizou essa concentração dos atributos divinos teve bastante orgulho desse progresso. Ele pôs à mostra o pai que desde sempre se ocultara, como um núcleo, em cada figura divina. [...] Agora que Deus era único, as relaçôes podiam reaver a intimidade e intensidade dos laços infantis com o pai. Mas, se fez tanto pelo pai, esse povo também quis ser recompensado, quis ser o único filho amado, o Povo Eleito." (FREUD, 2014, p. 252). 
A dívida de Freud para com Espinosa tampouco parece estar na Parte $\mathrm{V}$ da Ética, a qual trata da felicidade. Freud, como veremos, não acreditava na possibilidade de uma felicidade, que, em termos psicanalíticos, talvez correspondesse a algo como uma cura completa do paciente. Identificada a uma solução total dos dramas psicoafetivos de alguém, a felicidade produziria antes um mostro que um ser humano comum, uma espécie de "normopata", em vez de alguém saudável. ${ }^{3} \mathrm{O}$ motivo principal para a recusa freudiana da felicidade talvez esteja no fato de que sua ideia pudesse também ser colocada no mesmo campo das idealizações (fantasias) a que pertencem as noçôes metafísico-religiosas de Deus e seus equivalentes.

Excluídos os ideais de Deus e de Felicidade, partes I e V da Ética, sobram as partes II, sobre a mente, III, sobre a natureza e origem dos afetos, e IV, sobre a servidão afetiva. Descartamos, de um lado, as obras políticas particularmente o Tratado Político -, pelo fato de que não estavam no primeiro plano das preocupaçóes de Freud questóes de ordem política, embora ele tenha lido o Tratado teológico-político, por ocasião da redação de Moisés e o monoteísmo, em 1934. ${ }^{4}$ De outro lado, descartamos as outras obras em que Espinosa não desenvolveu plenamente suas principais ideias, como o Tratado da Emenda do Intelecto, o Breve Tratado e a Correspondência. Uma teoria da mente e dos afetos mais acabada e consistente, como a apresentada na Ética, deve ter interessado muito mais àquele que estava criando uma outra maneira de explorar os segredos da alma humana.

\footnotetext{
${ }^{3}$ Quando Freud falava em "cura”, era sempre a cura de uma enfermidade psíquica determinada, ou a solução para um sintoma específico. Por exemplo, Freud fala em cura do delírio de Hanold ("paciente") através de Zoé ("terapeuta"), em "O delírio e os sonhos na Gradiva de W. Jensen"; ou em cura da fobia do "pequeno Hans", em Análise da fobia de um garoto de cinco anos (1909).

${ }^{4}$ Michel Juffé, em obra recentemente publicada, relembrando o contato entre Freud e Romain Rolland, o qual durou mais de dez anos (1923-1936), afirma que, por volta de 1934, quando Freud estava ocupado com a redação de Moisés e o monoteísmo, Rolland o estimulou a ler, "[...] se possível no original latim”, o Tratado Teológico-Político (TTP). Segundo Juffé, após “[...] muita hesitação”, Freud, que, como se sabe, não era dado a leituras filosóficas, se póe enfim a ler Espinosa. Mas nem em Moisés nem em seus outros últimos textos, Freud cita Espinosa ou o TTP, embora, como escreve Juffé, os "[...] dois partilhem a ideia de que não existe Deus pessoal e que sua invenção pelos homens deve-se a seus temores e à sua relativa impotência no seio da natureza." (JUFFÉ, 2016, p. 9). Contudo, é muito provável que, sete anos antes, tenha sido também ao Espinosa do TTP que Freud estivesse se referindo, quando, em O futuro de uma ilusão, de 1927, escreveu: “[...] não afirmei nada que outros homens melhores não tivessem dito antes, de maneira bem mais completa, vigorosa e efetiva. Seus nomes são conhecidos; não os mencionarei, para não dar a impressão de que desejo me incluir entre eles. Eu apenas - é a única novidade em minha exposição - adicionei alguma fundamentação psicológica à crítica de meus grandes predecessores." (FREUD, 2014, p. 274).
} 
Ainda que a origem e natureza da mente seja deduzida da estrutura ontológico-metafísica demonstrada no De Deo, Parte I da Ética, a ideia inovadora de uma mente inseparável do corpo, uma mente que é essencialmente a ideia de seu corpo, táo ativa ou passiva quanto ele, mas que conserva sua autonomia ontológica frente a ele e, portanto, garante a singularidade da dimensão psíquica - uma tal ideia certamente poderia despertar bastante o interesse de Freud pelo pensamento espinosano.

Mais do que a teoria da mente, contudo, a atmosfera espinosana que, de algum modo, influenciou o trabalho de Freud talvez tenha sido sua maneira geométrica - que dentre outras coisas implica algo de imparcial e científico de elaborar um conhecimento sobre a mente e os afetos humanos. "Tratarei aqui dos afetos como se fosse questôes de linhas, pontos e retas", escreve Espinosa ,no prefácio ao De natura et origine affectibus (Parte III da Ética). Uma ciência dos afetos, portanto, era a proposta de Espinosa, e nada mais próximo do trabalho freudiano de construção da psicanálise enquanto ciência, embora, como já muito se disse, a "ciência" psicanalítica fosse ela mesma um rompimento com as concepçóes positivistas da psicologia e da psiquiatria do século XIX.

Conhecer os afetos humanos; não rir, não lamentar, não detestar as paixôes humanas, mas compreendê-las, escreve Espinosa no Tratado Político (ESPINOSA, 2009, p. 8). Esse quase axioma metodológico de Espinosa em nada é estranho ao trabalho psicanalítico. E certamente não são estranhos os efeitos terapêuticos desse conhecimento, ainda que os pressupostos sejam diferentes, nos dois casos.

Em Espinosa, há uma alegria envolvida no ato de conhecer a natureza e origem de todo e qualquer afeto. Não é muito diferente na psicanálise. Se o analisando procura a clínica, porque experimenta algum tipo de sofrimento psíquico, um efeito terapêutico lógico deve ser, no mínimo, uma diminuição desse sofrimento, o que já é uma forma de alegria. E o que se faz na clínica, em última instância? Busca-se, pelos métodos próprios do trabalho psicanalítico, conhecer o quanto possível as "causas", reais ou imaginárias, daquilo que está provocando a emergência de sintomas, que são maneiras de lidar com o sofrimento. Pouco importa que esse "conhecimento" náo seja de ordem propriamente filosófica ou causal. O fato é que, na análise, busca-se, de algum modo, a compreensão de uma "verdade" sobre si, isto é, uma interpretação do que se está passando, que faça sentido diante dos acontecimentos afetivos. 
Embora não se possa dizer que sejam ainda resultados de uma análise propriamente dita, reconhecem-se facilmente os efeitos terapêuticos daqueles momentos do trabalho psicanalítico em que nos deparamos com as "causas" (motivos, determinaçóes) que nos levam a agir de tal ou tal maneira, algo que não éramos capazes de perceber, antes da análise. É verdade que há também e isso é muito comum - momentos em que o efeito terapêutico é justamente o contrário: uma tristeza, em geral na forma da angústia, como, por exemplo, quando nos damos conta de que agimos exatamente como nossos pais, cujo comportamento vinha sendo, contudo, o objeto de nossas críticas, pelas quais buscávamos nos distanciar deles, por algum motivo.

Mas também a psicanálise, como o percurso ético espinosano, é um trabalho árduo, no qual a angústia não é algo a ser extirpado, mas precisamente a marca da entrada em análise, sem o que se permaneceria no mero terreno terapêutico. A angústia engendrada no processo analítico é, porém, diferente daquela com a qual o paciente muitas vezes chega à clínica. Inquietação mais profunda, ela não se reduz à mera perturbação do ânimo. Leva a novos questionamentos sobre a imagem de si próprio - esse fantasma que nos habita desde sempre, para falar à maneira de Lacan -, mais do que à prostração e resignação diante de si mesmo. Ela é condição necessária para ir além, para continuar o processo analítico, o qual, espera-se, deverá ter suas recompensas..

O campo do conhecimento dos afetos constitui, portanto, a área de intersecção entre Freud e Espinosa. Mas, se conhecer os afetos tem efeitos terapêuticos que nos dois casos são de mesma natureza (alegria, em Espinosa, diminuição ou supressão do sofrimento, na psicanálise), terão o mesmo sentido e significado? Freud poderia objetar que o espinosismo é apenas o conhecimento da estrutura geral dos afetos, e que esse conhecimento, no entanto, é deduzido da estrutura geral da Natureza - as leis de sua produção e funcionamento -, ou seja, Deus, algo que ele, Freud, não poderia admitir, já que no limite estariam pressupostas estruturas metafísicas, para explicar o humano, as quais se situam fora do escopo tanto da clínica quanto da metapsicologia. O mais importante no trabalho analítico é, na verdade, o conhecimento dos próprios afetos do analisando, dos afetos que pertencem à sua história singular. $\mathrm{O}$ espinosismo é conhecimento dos afetos humanos, mas seria ainda um conhecimento abstrato ou geral, podendo servir apenas como apoio ao trabalho do psicanalista que se debruça sobre casos singulares, sobre histórias particulares. 
É certo que esses dois aspectos podem ser complementares. A compreensão da natureza dos afetos, portanto, de todo e qualquer afeto, certamente deve ser útil ao conhecimento dos afetos particulares de cada um de nós e, assim, de nossa própria história afetiva. A maior diferença entre Freud e Espinosa, nesse caso, estaria antes na direção do caminho que cada um seguiu para compreender os afetos. Espinosa vai do conhecimento de Deus (a Natureza) ao conhecimento da natureza dos afetos humanos. Freud vai do conhecimento de histórias afetivas particulares obtidas no interior da clínica ao conhecimento dos afetos humanos em geral - vai da clínica (prática) à metapsicologia (teoria).

Essas duas direçôes opostas em relação ao modo de conhecer os afetos não se devem apenas a uma divergência de método. Elas assinalam o ponto em que Freud e Espinosa não poderiam estar mais distantes um do outro. Se Espinosa começa por Deus e chega aos afetos humanos, é porque sua "grande descoberta" é a noção de Causa sui, núcleo da definição de Deus ou Natureza. Se Freud parte de certas formaçóes constitutivas da afetividade (os complexos) e certas estruturas da psique humana (Id, Ego e Superego), é porque sua "grande descoberta" diz respeito à noção de inconsciente. Deus, num caso, e inconsciente, no outro, seriam os dois pontos de divergência entre Espinosa e Freud. E isso tem consequências importantes sobre a maneira como cada um deles compreende a potência terapêutica do conhecimento. Em ambos, o conhecimento - dos próprios afetos, antes de mais nada - produz efeitos terapêuticos que poderíamos reduzir ao afeto de alegria envolvido no ato de conhecer melhor a si mesmo, mas tem alcance diferente em cada um deles. Em Espinosa o conhecimento, no limite, pode levar o sujeito cognoscente a uma felicidade e liberdade, entendidas como "amor intelectual de Deus", que não se encontram na psicanálise. Entretanto, alguma felicidade e alguma liberdade devem estar também no horizonte psicanalítico..

\section{EM VEZ DE AMAR, PESQUiSOU: A SUbLIMAÇÃo DE LEONARdo}

Podemos entender melhor o lugar e o alcance do conhecimento, na psicanálise, se revisitarmos o famoso ensaio de Freud sobre Leonardo da Vinci. É um texto importante para os nossos propósitos, aqui, porque nele, em certo momento, Freud sugere uma aproximação entre Leonardo e Espinosa. Apenas uma sugestão, é claro, mas nós sabemos o valor que uma simples sugestão pode ter, em psicanálise. 
James Strachey, psicanalista e editor inglês das obras completas de Freud, em nota ao ensaio "Leonardo da Vinci e uma lembrança de infância", revela que o interesse de Freud pelo "enigma Da Vinci" já datava de pelo menos doze anos antes da publicação do ensaio, em 1910. Ele cita um trecho de uma carta de Freud a Fliess, escrita em 9 de outubro de 1898: "Leonardo, que talvez fosse o mais famoso canhoto da história, jamais tivera um caso de amor.” (FREUD, 1996, p. 69) . Já nessa passagem se encontra aquilo que, aos olhos de Freud, parecia ser o enigma de Leonardo, um grande artista e cientista, o qual, no entanto, náo tivera casos de amor e quase nenhuma atividade sexual (a confiar nos dados biográficos então disponíveis).

Na verdade, pela tese de Freud sobre Leonardo, em vez de "no entanto", deveríamos ter escrito "por isso mesmo". Uma das grandes teses freudianas, nesse ensaio, é esta: em Leonardo, o "artista" foi sendo substituído pelo "cientista", a arte foi dando lugar à investigação científica, através de um processo de sublimaçâo. ${ }^{5}$ Freud buscou compreender as razóes disso, aplicando conceitos e métodos clínicos da psicanálise, que, na primeira década do século XX, ainda não atingira o auge do seu desenvolvimento. Com base em importantes biógrafos antigos e de sua época, Freud (2013, p. 125) considerou que Leonardo passou praticamente toda a sua vida sem ter tido "casos de amor":

É duvidoso que Leonardo tenha alguma vez enlaçado amorosamente uma mulher; tampouco se tem notícia de alguma íntima relação espiritual com uma amiga, como a de Michelangelo e Vittoria Colonna. Quando ainda era aprendiz, vivendo na casa de seu mestre Verrocchio, foi alvo de uma acusação de prática homossexual ilícita juntamente com outros jovens, denúncia que terminou com sua absolvição.

\footnotetext{
${ }^{5}$ Se o interesse por Leonardo Da Vinci datava de fins do século XIX, o conceito de sublimação, em Freud, como se sabe, só aparecerá nos inícios do XX, nos textos publicados em 1905. Já em Análise fragmentária de uma histeria [o caso Dora], escrito em 1901, a sublimação aparece como o processo pelo qual a "[...] indiferenciada predisposição sexual da criança” é reprimida e direcionada "[...] para metas mais elevadas, assexuais - sublimaçẫo" - sendo através dela que emerge "a energia para bom número de nossas realizaçôes culturais." Aqui, sublimação é o exato oposto da perversão: o perverso é justamente aquele que năo foi capaz de sublimar; ele não "se tornou" perverso, mas "permaneceu assim"; sua sexualidade, por assim dizer, não se transformou, devido a uma "[...] inibiçấo do desenvolvimento." (FREUD, 2016, p. 229, grifos do autor). Permanece o mesmo: pois a criança já é perversus polimorphus. O conceito de sublimaçấo ganhará contornos mais nítidos em 1905, no segundo dos Três ensaios sobre a sexualidade, que trata justamente da sexualidade infantil: "Os historiadores da civilização parecem concordes em supor que, desviando-se as forças instintuais sexuais das metas sexuais para novas metas - um processo que merece o nome de sublimação - adquirem-se fortes componentes para todas as realizaçóes culturais. Acrescentaríamos que o mesmo processo ocorre no desenvolvimento do indivíduo, e situaríamos seu começo no período de latência sexual da infância." (FREUD, 2016, p. 80-81).
} 
A ideia de um Leonardo homossexual já era conhecida nos tempos de Freud, o qual tentará dar também para isso uma explicação psicanalítica. ${ }^{6}$ Mas o centro das preocupaçóes freudianas é, ao nosso ver, não a homossexualidade, mas antes a "assexualidade" de Leonardo ${ }^{7}$, que, quando mestre, era rodeado de jovens e belos alunos, com os quais mantinha relaçôes afetuosas, porém não sexuais. Mais cauteloso que os biógrafos, que negavam como um insulto ao grande artista a possibilidade de que ele mantivesse relaçóes sexuais com seus alunos, Freud considera "muito mais provável" que as "[...] afetuosas relações entre Leonardo e aqueles jovens que participavam de sua vida, como era costume dos discípulos naquele tempo, não resultavam em atos sexuais", acrescentando, logo em seguida: "Além disso, não podemos lhe atribuir um grau intenso de atividade sexual." (FREUD, 2013, p. 129-130).

Não importa, aqui, a questão da autenticidade biográfica que embasa a tese. Sabe-se que o último dos alunos de Leonardo, Francesco Melzi, como escreve o próprio Freud, "[...] acompanhou-o à França, ficou a seu lado até a sua morte e foi por ele nomeado seu herdeiro.” (FREUD, 2013, p. 129-30). Melzi foi provavelmente, além de amigo e aluno, o companheiro amoroso de Da Vinci, que conviveu com ele por mais de uma década. E, nesse caso, restaria saber mais sobre a vida sexual entre ambos. Mas o próprio Leonardo teve que esconder suas relaçôes amorosas homoafetivas, por ter sido preso por dois meses, na juventude, sob a acusação de sodomia ativa. Escreve Roudinesco (2016, p. 190):

Logo, não havia em Leonardo "relaçóes ambíguas" com os homens, e sim amores dissimulados ao longo de sua vida para escapar ao risco da condenação à morte. E é pouco provável que tenha sido, como pensava Freud, um homem "sexualmente inativo" que, por meio de uma

${ }^{6} \mathrm{O}$ psicanalista contemporâneo Juan-David Nasio resume bem a clássica tese psicanalítica sobre a homossexualidade masculina; vamos reproduzi-la, aqui, porque, em linhas gerais, é a mesma que está presente no ensaio sobre Leonardo. Nasio escreve: "A psicanálise considera que a homossexualidade [masculina] foi provocada por uma interrupção da evolução sexual do menino, devido a um transbordamento de ternura materna que submerge a criança. A ternura excessiva da mãe pelo filho buscando frequentemente compensar a ausência do marido - paralisa a criança imatura em um excesso de prazer que ela é obrigada a suportar. [...] Mas tarde o menino, que se tornou um rapaz, fortemente impregnado pelo prazer de outrora, buscará imperiosamente encontrar a mesma volúpia e a mesma felicidade. Tal busca de sensualidade se torna para ele tâo onipresente que modela seu corpo e lhe impóe uma maneira de amar. [...] nessa ficção a mãe desempenha o papel de uma mulher sedutora e o menino, o de uma criança seduzida. Ora. Acontece que, sem se dar conta, o homossexual projeta essa fantasia na realidade de seu casal. Desempenha indiferentemente, e faz seu companheiro desempenhar, ambos os papeis, mãe e filho." (NASIO, 2003, p. 56-57).

7 Veremos, logo a seguir, que Peter Gay e Roudinesco, em suas belas biografias de Freud, divergem nesse ponto. Ver nota 18 , abaixo. 
sublimação, teria convertido sua sexualidade numa pulsão de saber. Viveu até a morte na companhia de Melzi, de quem fará seu herdeiro.

Freud, todavia, não se ocupou com essas questóes. $\mathrm{O}$ que nos importa, antes de tudo, é a própria formulação freudiana da tese: Leonardo dedicou-se tanto mais à pesquisa científica quanto menos amou. $\mathrm{O}$ elemento intelectual, o conhecimento, a pesquisa - tudo isso o afasta do amor, da paixão e do sexo. Contrariando dados biográficos, sabemos atualmente o quanto essa tese falava mais sobre o próprio Freud do que sobre Leonardo: "Manifestamente", escreve Roudinesco, "Freud projetava seu culto da abstinência sobre esse gênio intensamente admirado. $\mathrm{Na}$ verdade fora ele, e não Leonardo, que convertera a pulsão sexual em pulsão criadora.” (ROUDINESCO, 2016, p. 190). A partir de 1893, Freud, de fato, renunciará a uma vida sexual regular com sua esposa, Martha, que, no intervalo de oito anos, dera à luz os seis filhos do casal (ROUDINESCO, 2016, p. 64.). Em suma, o ensaio sobre Leonardo é, antes de tudo, uma reflexão sobre a maneira como o próprio Freud compreendia a relação entre amor e conhecimento. ${ }^{8}$ É essa compreensão que nos interessa aqui.

$\mathrm{O}$ que ocorreu com Leonardo, segundo Freud? Para ele, o "instinto de pesquisa"9 pode derivar de três caminhos possíveis, ligados aos primeiros "interesses sexuais" da criança, que estão na base de todo o "[...] período da investigação sexual infantil." (FREUD, 2013, p. 137). Tudo vai depender, em última análise, da maneira como se resolve o destino da libido após esse período. No primeiro caso, não conseguindo dar uma resposta satisfatória à repressão sexual ligada ao édipo, “[...] a ânsia de saber é inibida”, escreve Freud, "[...] e a livre atividade da inteligência talvez fique limitada por toda a vida". Freud nomeia esse primeiro caso de "inibição neurótica" (FREUD, 2013, p. 139). No segundo caso, há resistência à repressão sexual, porque “[...] o desenvolvimento intelectual é forte o bastante" para tanto, mas as primeiras pesquisas sexuais suprimidas retornam do inconsciente e assumem a forma de uma "ruminação compulsiva", e, portanto, sob uma "[...] forma distorcida e contrita, mas forte o suficientemente”, escreve Freud, “[...] para sexualizar o

\footnotetext{
${ }^{8}$ Diferentemente de Roudinesco, a interpretação de Peter Gay segue outro caminho, enfatizando antes um Freud tendo que lidar, de um lado, com sua homossexualidade, presente sobretudo em sua relação com Fliess, mas também com Adler e Jung; de outro lado, com a questão do componente homossexual no distúrbio de paranoia (GAY, 2012, p. 276-286).

9 Alguns anos mais tarde, Freud usará a expressão "instinto de saber", por exemplo, nos acréscimos realizados, em 1915, ao segundo dos "Três ensaios sobre a sexualidade", texto publicado inicialmente em 1905 (FREUD, 2016, p. 103).
} 
pensamento mesmo e tingir as operaçóes intelectuais com o prazer e a angústia dos processos sexuais propriamente ditos." Neste caso, a própria pesquisa torna-se sexual, "frequentemente a única", afirma Freud, e "[...] a sensação de solucionar em pensamentos, de clarificar, toma o lugar da satisfação sexual." (FREUD, 2013, p. 139). Aqui, contudo, tal como na infância, a pesquisa nunca termina e o pesquisador nunca encontra uma satisfação plena.

Nesses dois primeiros casos, todo o problema reside no fato de que o "instinto de pesquisa" deve-se apenas ao "retorno do inconsciente", dos conteúdos recalcados no período das investigaçóes sexuais que então foram reprimidas. Por esse motivo, neles, o "instinto de pesquisa" se realiza, ou sob a forma da inibição neurótica, ou sob a forma da neurose compulsiva.

Há, no entanto, um terceiro tipo, "o mais raro e mais perfeito", segundo Freud, em que o elemento da neurose está ausente; ele "[...] escapa, graças a uma disposição especial, tanto à inibição do pensamento como a compulsão neurótica ao pensamento." "É certo que a repressão sexual também surge â̂", escreve Freud, "[...] mas náo consegue relegar ao inconsciente um instintivo parcial do prazer sexual." Nesse caso, a libido é sublimada desde o início "em ânsia de saber" e liga-se "ao vigoroso instinto de pesquisa, reforçando-o." Aqui, a pesquisa, que até certo ponto é também compulsiva, torna-se um substituto para a atividade sexual, mas, ao contrário dos dois primeiros casos, agora sem o elemento da neurose, porque ela decorre do "processo psíquico subjacente" de sublimação e não de "irrupção desde o inconsciente." O caso de Leonardo, segundo Freud, se apresenta como exemplo desse terceiro tipo, porque "[...] conseguiu sublimar em impulso à pesquisa a maior parte de sua libido." (FREUD, 2013, p. 140). ${ }^{10}$

\section{A DUREZA DA CIÊNCIA E OS DELEITES DO AMOR}

Freud considera que uma frase de Leonardo "[...] fornece a sua profissão de fé e a chave para a sua natureza." A frase é esta, tal como se encontra no ensaio sobre Da Vinci: "Nessuma cosa si può amare nè odiare, se prima non se há cognition di quella." (DA VINCI apud FREUD, 2013, p. 131).

E eis como Freud a traduz e interpreta: "Ou seja: não se tem o direito de amar ou odiar algo, se não adquirimos antes um conhecimento

\footnotetext{
${ }^{10}$ Observe-se que, como Freud estava às voltas com Da Vinci, em torno de 1898, é possível que este tenha sido o exemplo histórico por excelência que embasaria, mais tarde (1901-1905), seu conceito de sublimação.
} 
aprofundado de sua natureza" (FREUD, 2013, p. 131). Vê-se que o "si può", "se pode", tornou-se "se tem o direito"; o "profundo" é simplesmente um livre acréscimo de Freud, para quem Leonardo intelectualiza os objetos de amor. Corroborando sua interpretação, cita uma passagem do Trattato dela Pittura, em que Leonardo afirma:

[...] porque o grande amor nasce do grande conhecimento da coisa que se ama, e se tu não a conheceres, não poderás amá-la, ou apenas muito pouco. (DA VINCI apud FREUD, 2013, p. 131).

Essa intelectualização do processo amoroso é, segundo Freud, simplesmente falsa. Não é assim que se ama ou se odeia o que quer que seja. Os humanos não adiam "seu amor ou seu ódio", ele escreve, "[...] até haverem estudado os objetos desses afetos e distinguido sua natureza"; dá-se antes o oposto: "[...] elas amam impulsivamente, segundo motivos sentimentais que não têm relação com o conhecimento e cujo efeito é, no máximo, atenuado pela ponderação e reflexão." (FREUD, 2013, p. 131). Sabendo "tão bem quanto nós" da falsidade dessa prioridade do "grande conhecimento" do objeto amado em relação ao sentimento de amor por ele, o que Leonardo estaria então afirmando? Não algo que é, mas como deveria ser, uma espécie de imperativo categórico, "deve-se":

[...] deveríamos amar de modo a reter o afeto, submetê-lo ao labor do pensamento e deixá-lo tomar seu curso apenas depois de ser aprovado no exame do pensar. E nisso compreendemos que ele pretende nos dizer que com ele é assim; que seria desejável que todos os demais tivessem, para com o ódio e o amor, a mesma atitude que ele. (FREUD, 2013, p. 132).

Contudo, de qual amor se trata? A que tipo de amor Leonardo se refere?

$\mathrm{Na}$ passagem do Trattato citada por Freud, em que o "grande amor" depende do "grande conhecimento", Leonardo, segundo ele, parece estar se defendendo da acusação de ateísmo. Sem entrar na questão sobre qual seria de fato seu contexto, citemos a passagem inteira, tal como o próprio Freud o fez:

Mas calem-se tais repreendedores, pois esse é o modo de conhecer o operador de tantas coisas admiráveis e esse é o modo de amar tamanho inventor, porque o grande amor nasce do grande conhecimento da coisa 
que se ama, e se tu não a conheceres, não poderás amá-la, ou apenas muito pouco. (DA VINCI, 2013, p. 132). ${ }^{11}$

Para os propósitos do nosso ensaio, o que Leonardo pensava sobre a relaçáo entre amor e conhecimento importa menos do que aquilo que o próprio Freud disse e pensava a respeito. E, a esta altura, não há dúvidas: o conhecimento do objeto amado neutraliza o amor até o ponto de substituí-lo pela pesquisa.

Voltemos à primeira frase de Leonardo, citada por Freud: "Nessuma cosa si può amare nè odiare, se prima non se há congnition di quella." Extraída da Conferenze Fiorentine, essa ideia se tornará quase um axioma, mais tarde, no século XVII. Para que algo ou alguém possa ser objeto de amor ou ódio, é necessário que primeiro seja objeto de uma ideia, isto é, seja conhecido. $\mathrm{O}$ argumento, no fundo, é muito simples: não se pode dizer que se ama ou se odeia, digamos, bolo de macadâmia, se não se conhece macadâmia. Para amar ou odiar alguma coisa, preciso conhecer essa coisa, isto é, ter uma ideia (cognizione) dela. Dois séculos mais tarde, Espinosa (2015a, p. 127-28) dirá o mesmo, embora no estilo geométrico com o qual redigiu sua Ética:

Modos de pensar como amor, desejo, ou quaisquer outros que sejam designados pelo nome de afeto do ânimo, não se dáo se no mesmo indivíduo não se der a ideia da coisa amada, desejada etc. Mas a ideia pode dar-se ainda que náo se dê nenhum outro modo de pensar.

Há uma prioridade ontológica da ideia enquanto tal em relação aos modos de pensar. No caso do objeto amado (ou odiado etc.), o próprio afeto de amor (ou ódio etc.), enquanto modo de pensar, só se dá quando há a ideia do objeto amado. Mas não é assim que Freud interpreta a frase de Leonardo. Ele toma cognizione como "conhecer profundamente" e considera que o elemento intelectual, a reflexão, o "pensar sobre”, seriam as condiçôes necessárias para o amor ou ódio. Confunde ideia do objeto amado com conhecimento dele, ou, numa linguagem espinosana, ideia da ideia. A interpretação faz o amor ao objeto depender de reflexôes, consideraçôes, ponderaçóes sobre o objeto. Mas

${ }^{11}$ DA VINCI, Tratado de pintura, citado por Freud, OC, V. 9, p. 132. O texto original é este: "Ma tacciano tali riprensori, ché questo è il modo de conoscere l'operatore di tante mirabili cose, e questo è il modo di amare un tanto inventore, perché invero il grande amore nasce dala gran cognizione della cosa che si ama, e se tu non la conoscerai, poco o nulla la potrai amare". Cf. DA VINCI, L. Trattato della pittura. Milano: TEA, 1995, \$74, p. 64-65. 
eis o problema: esse processo "intelectualizador", sem dúvida "antinatural", teria precisamente o efeito de neutralizar o afeto, substituindo-o pela própria ação de conhecimento:

Postergar o amor até que se adquira o conhecimento resulta na substituição daquele por este. Tendo chegado a conhecer, o indivíduo já não ama ou odeia de fato; encontra-se além do amor e do ódio. Talvez por isso a vida de Leonardo tenha sido mais pobre de amor do que a de outros grandes homens e artistas. As tempestuosas paixôes que exaltam e consomem, a que outros deveram o melhor de sua vida, parecem não tê-lo atingido. E há outras consequências. O individuo pesquisou, em vez de agir e criar. (FREUD, 2013, p. 133-34, grifos nossos).

Leonardo, em suma, assim como não age nem cria, mas pesquisa, também não ama, mas investiga. Nele, o sentimento de amor estaria sujeitado à reflexão, devendo "[...] ser aprovado no exame do pensar" (FREUD, 2013, p. 132).

Fruto de uma "sede insaciável e incansável de conhecimento", que, por fim, substituiria o próprio amor, essa intelectualização do amor, em Leonardo, seria uma experiência, segundo Freud, próxima a de um outro grande pensador, igualmente conhecido por ter amado pouco e "investigado" muito: Espinosa. Escreve Freud:

Devido a seu insaciável e incansável ímpeto de pesquisa, Leonardo foi chamado de Fausto italiano. Mas, sem considerar as dúvidas quanto à possível reconversáo do instinto de pesquisa em prazer de viver, que temos de ver como o pressuposto na tragédia de Fausto, pode-se arriscar a observação de que o desenvolvimento de Leonardo se aproxima do modo de pensar spinoziano. (FREUD, 2013, p. 133).

Como Leonardo, também Espinosa teria substituído o amor pela "investigação"? Importa pouco saber, aqui, se Espinosa amou tanto menos quanto mais "investigou", ou se sua vida, como a de Leonardo, na visão de Freud, foi tão "mais pobre de amor", quanto mais rica foi em investigaçóes científicas. Interessa antes saber se faz sentido a oposição freudiana entre amor e conhecimento, oposição que aparece também claramente num outro ensaio de Freud, escrito no mesmo ano, Um tipo especial de escolha de objeto feita pelo homem - Contribuiçóes à psicologia do amor I, em que Freud escreve, logo na abertura do texto: 
[...] é inevitável que a ciência, com uma mão mais pesada e menor obtenção de prazer, venha a se ocupar das mesmas matérias cuja elaboração poética deleita os seres humanos há milênios. Essas observaçôes talvez justifiquem uma abordagem estritamente cientifica da vida amorosa humana. Pois a ciência é a mais completa renúncia do princípio do prazer que a nossa atividade psíquica é capaz de fazer. (FREUD, 2013, p. 335).

De passagem, observemos que, nesse ensaio, Freud considera que a atividade intelectual dos escritores (poetas e romancistas), objetivando "[...] prazer intelectual e estético, assim como determinados efeitos emocionais", não pode por isso mesmo alcançar os núcleos de verdade da vida amorosa (FREUD, 2013, p. 335). Em outras palavras, o prazer distorce a realidade e o conhecimento da realidade neutraliza o prazer, o qual só está envolvido na atividade intelectual sob a condição de que ela vise, não à verdade, mas ao próprio prazer. Tudo se passa como se devêssemos escolher: ou bem a dureza da ciência, ou bem os deleites do amor.

\section{Afeto e COGNIÇÁo}

Essa distância que separa afeto e conhecimento é inteiramente estranha à filosofia de Espinosa. $\mathrm{O}$ próprio afeto é um tipo de conhecimento, porque ele é uma ideia, uma expressão psíquica que exprime a variação da potência de agir da mente simultânea a uma afecção do corpo pela qual a potência deste igualmente varia. $\mathrm{O}$ afeto, em Espinosa, é um acontecimento do corpo (afecção) e da mente que dele é ideia, simultaneamente, pois é da essência da mente ser uma ideia da totalidade do seu corpo (as relaçôes de proporção de movimento e repouso que o definem) e do que nele se passa (as variaçóes de sua potência de agir). Se essa ideia for confusa, parcial, a qual só se explica por nossa relação com a exterioridade, o afeto é passivo, é uma paixão; porém, se for uma ideia adequada do que se passa em nós, que depende unicamente de nossa potência de pensar para se explicada, o afeto é ativo, é uma ação. $\mathrm{O}$ afeto ativo é sempre uma alegria, não só porque é aumento de nossa potência de agir e de pensar, mas porque o é segundo a própria potência interna para o conhecimento adequado. $\mathrm{O}$ afeto passivo pode ser uma alegria ou uma tristeza, isto é, um aumento ou uma diminuição da potência de agir do corpo e de pensar da mente. Paixóes, portanto, podem ser tanto alegres quanto tristes (ESPINOSA, 2015a, p. 237). 
Qual a marca da paixão? A dependência da exterioridade. Dependemos da posse, do uso e do gozo de bens exteriores, para ter nossa potência de agir e pensar aumentada, ou seja, para sermos alegres. Somos determinados a buscar sempre alegrias - ainda que, às vezes, pelas formas mais bizarras e contrárias possíveis - porque somos conatus, esforço em perseverar na existência, algo que decorre do fato de sermos partes intrínsecas, expressóes imanentes das açôes dos atributos Extensão e Pensamento que constituem a essência da Natureza ou Deus, cuja essência é existência e portanto existe necessariamente. ${ }^{12}$ Existir necessariamente, em Deus, significa autoproduzir-se e, ao mesmo tempo e no mesmo sentido, produzir as infinitas coisas e as infinitas ideias que decorrem necessariamente da essência eterna e infinita de Deus. ${ }^{13}$ Nós somos uma dessas coisas, que, exprimindo de maneira certa e determinada a essência eterna e infinita da Natureza, busca perseverar na existência: somos, portanto, um conatus, esforço em manter e aumentar a potência de ser e existir (ESPINOSA, 2015a, p. 251).

Conscientes desse esforço, somos essencialmente desejo ${ }^{14}$ e, assim, por natureza, desejamos tudo o que possa aumentar a potência de existir, ou seja, tudo o que é causa de alegria. Ocorre, entretanto, que o campo da passionalidade é também o campo da contrariedade e da ambivalência. Dependentes da exterioridade para existir, isto é, ser, viver e agir, nem sempre o que desejamos é realmente bom ou útil para a nossa existência. Sendo a paixão uma ideia confusa e parcial, não sabemos certamente se o que desejamos é realmente útil ao nosso esforço de perseveração na existência. E, mesmo que um objeto desejado seja bom em certo momento e sob certas condiçóes, pode deixar de ser em outro momento e sob outras condiçôes. Ou então, algo que nos faz bem pode ser causa indireta de algum mal, como quando ingerimos uma quantidade excessiva de alimento. Dada a alegria causada, por exemplo,

\footnotetext{
${ }^{12}$ Aqui, somos obrigados a remeter o leitor às Partes I e II da Ética de Espinosa, onde são demonstradas a essência de Deus como Substância única e ser absolutamente infinito, constituído de infinitos atributos infinitos em seu gênero, dos quais conhecemos dois: o atributo Extensão, do qual decorrem infinitos seres corporais de infinitas maneiras, dentre os quais o corpo humano, e o atributo Pensamento, do qual decorrem infinitas ideias de infinitas maneiras, dentre as quais a mente humana, que é uma ideia determinada de um corpo determinado existente em ato (ESPINOSA, 2015, p. 45-46, 49-57).

${ }_{13}^{13}$ É somente assim que Deus, ou Natureza, pode existir, autoproduzindo e, no mesmo ato, engendrando imanentemente infinitas coisas de infinitas maneiras, pois é um ser constituído de atributos eternos e infinitos, os quais são, eles mesmos, essências atuosas (essentia actuosa).

14 "O Desejo é a própria essência do homem enquanto é concebida determinada a fazer [agir] algo por uma dada afecção sua.” (ESPINOSA, 2015, p. 339).
} 
pelo alimento, somos determinados a desejá-lo; pela tristeza do desconforto causado pelo excesso, somos determinados a rejeitá-lo.

Mas podemos conviver com os dois estados, oscilando entre um e outro, se o afeto de tristeza não for forte o suficiente para nos levar a rejeitar isso que também é causa de alegria ou prazer. Permaneceremos aí, também, se nenhum outro afeto, contrário e mais forte, não vier determinar a mudar o estado de coisas. O que é importante, aqui, é que essa alegria passiva ou paixão alegre é acompanhada da ideia da existência e presença do objeto exterior como causa - e é isso que constitui o amor.

Vemos entấo o quanto, em Espinosa, conhecimento e afeto, de um modo geral, e conhecimento e amor, especificamente, constituem dimensóes de um mesmo estado cognitivo-afetivo. Todo afeto envolve uma dimensão cognitiva, porque se constitui como ideia do que se passa em nós, expressão psíquica das variaçóes da potência de agir e pensar da mente, enquanto ideia de um corpo cuja potência simultaneamente varia. $\mathrm{O}$ conhecimento não neutraliza o amor, como em Freud, mas é o próprio amor, quando se trata da ideia de algo que se sabe ou se imagina ter sido a causa de um aumento da potência de agir. Amamos o que conhecemos e somente o que conhecemos, já que o amor é a alegria acompanhada da ideia (conhecimento) de uma causa exterior.

Mas toda essa argumentação em torno da relação intrínseca entre afeto e conhecimento pode náo ser suficiente para refutar a tese de Freud, de que o conhecimento neutraliza o amor - aquele que conhece não ama nem odeia, estando acima de amor e ódio -, se tomarmos conhecer como "objetivar", "intelectualizar" ou "investigar sobre", isto é, não simplesmente ter uma ideia do objeto amado - dimensão cognitiva do afeto -, mas saber sobre ele. Nesse caso, o conhecimento desencantaria, por assim dizer, o próprio afeto de amor?

\section{UM PRAZER QUE DESENCANTA, UM AMOR QUE SE DESFAZ}

O que é o amor, em Freud? Ao contrário de Espinosa, ele náo oferece uma definição precisa. Não surpreende, uma vez que o amor não é uma substância, uma coisa, mas sim um afeto e, portanto, se inscreve na ordem das relaçôes dos homens consigo mesmos, deles entre si e deles com as coisas. Embora Espinosa tenha uma definição precisa - mas não única - de amor, também nele o amor é um afeto que se dá nas relaçôes, já que pressupóe uma 
relação com a exterioridade, no caso do amor passional, e consigo mesmo, como parte da Natureza, no caso do amor ativo. ${ }^{15}$ Numa palavra, amor é sempre relação amorosa.

Nessa relação, segundo Freud, a libido e o objeto do desejo estão sempre implicados, constituindo sua base ontológica. Dado o princípio do prazer algo que poderíamos encontrar, por outros caminhos, tanto em Epicuro como em Espinosa - e a primazia da sexualidade, o amor, em Freud, tem sempre como objetivo - explícito ou implícito, direto ou indireto, consciente ou inconsciente - a realização de impulsos que são de ordem sexual. Numa de suas raras, talvez única, entrevistas, concedida a um jornalista norte-americano, George Sylvester Viereck, em 1926, Freud disse:

Eu posso ter errado em muitas coisas, mas estou certo de que náo errei ao enfatizar a importância do instinto sexual. Por ser tão forte, ele se choca sempre com as convençôes e salvaguardas da civilização. A humanidade, em uma espécie de autodefesa, procura negar sua importância. Se você arranhar um russo, diz o provérbio, aparece o tártaro sob a pele. Analise qualquer emoção humana, não importa quáo distante esteja da esfera da sexualidade, e você certamente encontrará esse impulso primordial, ao qual a própria vida deve a perpetuaçáo. (FREUD apud SOUZA, 1990, p. 126).

O fundo, a base de qualquer afeto, é habitada pelo instinto sexual. É por isso que o amor propriamente sexual oferecerá como que um "modelo de felicidade", só não exclusivamente perseguido por causa do sofrimento e do desamparo frequentemente envolvidos no modo de vida que póe o amor (sexual) à frente e acima de qualquer coisa. Em $O$ mal-estar na civilizaçâa, Freud escreve:

Estou falando, claro, daquela orientação de vida que tem o amor como centro, que espera toda satisfação do amar e ser amado. Essa atitude psíquica é familiar a todos nós; uma das formas de manifestação do amor, o amor sexual, nos proporcionou a mais forte experiência de uma sensação de prazer avassaladora, dando-nos assim o modelo para nossa busca da felicidade. Nada mais natural do que insistirmos em procurá-la no mesmo caminho em que a encontramos primeiro. (FREUD, 2010, p. 39).

\footnotetext{
${ }^{15}$ É por isso que há duas definiçôes de amor, a que é oferecida na Parte III, o afeto de amor inscrito na passionalidade, e a que é oferecida na Parte V, o "amor intelectual de Deus", o qual se dá no campo da ação, da felicidade e da liberdade.
} 
Entretanto, logo acrescenta:

O lado frágil dessa técnica de viver é patente; senão, a ninguém ocorreria abandonar esse caminho por outro. Nunca estamos mais desprotegidos ante o sofrimento do que quando amamos, nunca mais desamparadamente infelizes do que quando perdemos o objeto amado ou o seu amor. Mas com isso não encerramos o tema da técnica de vida baseada no valor de felicidade do amor. (FREUD, 2010, p. 39).

A felicidade é impossível, para Freud, porque sempre podemos perder nosso objeto de amor, o amor do nosso objeto amado ou, o que é ainda pior, nossa própria capacidade de amar e ser amado, quando, diante do desamparo e das perdas de objeto, somos levados a uma perda de nós mesmos e caímos na melancolia ou depressão (FREUD, 1917). Ainda em O mal-estar na civilização, ele escreve: "O programa de ser feliz, que nos é imposto pelo princípio de prazer, é irrealizável.” (FREUD, 2010, p. 40). A felicidade é impossível porque equivaleria a obter do mundo externo uma plena satisfaçáo do desejo regido pelo princípio do prazer. Mas o mundo não pode ser plenamente moldado ao nosso desejo, embora vários caminhos possam ser seguidos, para contornar o problema e pelo menos nos aproximar de uma felicidade possível. "Em nenhum desses caminhos", contudo, "[...] podemos alcançar tudo o que desejamos", e a felicidade, entendida por Freud num "sentido moderado em que é admitida como possível”, será simplesmente um "[...] problema da economia libidinal do indivíduo", dependendo, em última análise, do quanto podemos tirar satisfaçáo do mundo real, tornarmo-nos independente dele e alterá-lo, adaptando-o aos nossos desejos (FREUD, 2010, p. 40).

O ideal de felicidade nasce do princípio de prazer, mas o princípio de realidade, sempre presente - a não ser nas mais diversas formas de enfermidades psíquicas - mostra os limites da realização desse ideal. O trabalho de conhecimento, nesse caso, ocupa um lugar peculiar dentre as atividades humanas passíveis de serem levadas a cabo como caminhos possíveis para uma felicidade factível. Como todas as outras grandes atividades humanas - religião, estética etc. - o conhecimento tem como "móvel" ou "força motivadora" (Triebfeder), para além da busca da "utilidade", a "obtenção de prazer" (FREUD, 2010, p. 55-56). Entretanto, o conhecimento tem a peculiaridade de, sendo meio de prazer, implicar, senáo um desprazer, pelo menos uma neutralização do estado prazeroso, pois o conhecimento nos coloca em contato com o real tal como ele é. Toda a questão do autoconhecimento conduzido pelo trabalho analítico é 
proporcionar ao analisando a capacidade de amar e ser amado malgré tout, ou não obstante si mesmo e o mundo.

É por isso que o processo analítico é permeado de angústia: nem sempre é prazeroso encarar-se a si mesmo. O trabalho de conhecimento envolve o conhecimento da realidade e o real nem sempre é prazeroso. Por esse motivo, embora possa ser exercido como meio de obtenção de prazer, esse prazer é permeado de tristeza: o mundo não é lá grande coisa, e nós mesmos não somos tão especiais como imaginávamos que nossos pais gostariam. $\mathrm{O}$ homem de conhecimento, mesmo assim, encontrará mais prazer em conhecer o real tal como ele é, resignando-se, quando o conhecimento mostra que o real é diferente do que ele desejaria. Tudo se passa, então, como se o trabalho de conhecimento fosse a melhor forma de conjugar princípio do prazer e princípio de realidade, o que talvez seja a única forma de felicidade possível em Freud.

A atividade de conhecimento, em suma, é um prazer que desencanta os objetos de estudo, mas o contato com o real não é necessariamente um desprazer; pode se constituir numa forma de prazer resignado diante da impossibilidade da felicidade. Freud tinha setenta anos quando deu a entrevista a que nos referimos acima. A certa altura, o entrevistador fez o seguinte questionamento:

Às vezes imagino se não seríamos mais felizes caso soubéssemos menos dos processos que dáo forma a nossos pensamentos e emoçôes. A psicanálise rouba à vida seu último encanto, ao relacionar cada sentimento ao seu grupo original de complexos. Não nos tornamos mais alegres descobrindo que nós todos abrigamos em nossos coraçóes o selvagem, o criminoso, o animal. (FREUD apud SOUZA, 1990, p. 123).

A réplica de Freud revela uma certa "melancolia": "Que objeção pode haver contra os animais? Eu prefiro a companhia de animais à companhia humana." E quando o entrevistador perguntou por que, Freud respondeu:

Porque são tấo mais simples! Não sofrem de uma personalidade dividida, da desintegraçáo do ego, que resulta da tentativa do homem de adaptarse a padróes de civilizaçáo demasiado elevados para o seu mecanismo intelectual e psíquico. O selvagem, como o animal, não tem a maldade do homem civilizado. A maldade é a vingança do homem contra a sociedade, pelas restriçóes que ela impóe. As mais desagradáveis características do homem são geradas por esse desajustamento precário a uma civilização complicada. (FREUD apud SOUZA, 1990, p. 124). 
Onze anos mais tarde, dois anos antes de sua morte, o tom pessimista de Freud diante do conhecimento se acentua. Numa carta de 13 de agosto de 1937, a Marie Bonaparte, Freud escreveu:

No momento em que nos perguntamos sobre o valor e o sentido da vida, estamos doentes, pois objetivamente tais coisas não existem. Ao fazê-lo, apenas admitimos possuir um quê de libido insatisfeita, a que algo mais deve ter acontecido, uma espécie de fermentação que conduz à tristeza e à depressão. Essa minha explicação não é grande coisa, certamente. Talvez porque eu mesmo seja muito pessimista. (FREUD apud SOUZA, 1990, p. 129).

Essa fala, na qual poderíamos entrever a sombra de Nietzsche ou mesmo a de Schopenhauer, nos permite vislumbrar os limites do conhecimento, em Freud. O prazer que o trabalho de conhecimento envolve se deve ao fato de nos tornar mais psiquicamente saudáveis, ao deixar enfim a razão falar, colocando-nos em contato com o real e com aquilo que realmente somos. Qualquer elaboração teórica, filosófica, metafísica ou religiosa que, por assim dizer, desse um passo além do real (tanto físico quanto psíquico, simbólico e imaginário) era vista por Freud com desconfiança. A clínica informa a teoria, sempre, e não o contrário. Confiemos sempre nos dados, nunca além deles.

Todavia, não é só a empiria do real que impõe limites ao conhecimento. O trabalho de conhecimento é uma ação que se dá no terreno da consciência. Sob ela, entretanto, está lá, sempre operante, o inconsciente, esse conceito freudiano por excelência. $\mathrm{O}$ inconsciente, instância que impede que o eu seja "senhor em sua própria casa”, não apenas é algo distinto da consciência, mas, como sabemos, resiste a ela, ou entâo estabelece com ela certas "formaçóes de compromisso" que satisfaz a ambos. Isso pode impedir que alcancemos certos conhecimentos, ou deixemos de conhecer certas verdades, principalmente quando são verdades sobre nós mesmos e que não desejamos conhecer. $\mathrm{O}$ trabalho do analista será, em parte, remover as resistências, os obstáculos, porém, não é garantido que analista e analisando obterão êxito..

De tudo isso, o que podemos extrair, se quisermos voltar à tese freudiana sobre o conhecimento em Leonardo Da Vinci?

Leonardo não ama, pesquisa. $\mathrm{O}$ conhecimento, nele, substituiria todos os seus casos de amor; ele colocaria a ação de conhecer à frente e acima do amor, neutralizando-o. Uma vez que o conhecimento, como todos os outros campos da atividade humana, apenas oferece um substituto para o modelo 
de felicidade (cuja base são as mais intensas fontes de prazer envolvidas no amor sexual) e como, além disso, desencanta os ideais de amor que recaem sobre o objeto (no caso da libido objetal) ou sobre si mesmo (no caso da libido narcísica), ele não pode, enquanto conhecimento, ser fonte de uma "felicidade", de uma alegria experimentada no próprio ato de conhecer e, portanto, de um "amor intelectual", num sentido espinosano da expressão.

Freud, é verdade, como vimos antes, cogita a possibilidade de "transformação da pulsão de investigação em prazer de viver" - e, nesse caso, pode-se deduzir, Espinosa estaria mais próximo do Fausto do que de Leonardo. Mas, se o próprio "instinto de investigação" remete à "libido sexual", no limite repetindo o gesto da criança curiosa que pergunta tudo e obtém muitas respostas, menos ao que ela realmente gostaria de saber - de onde realmente vim, ou veio ou virá meu irmáozinho, ou então o que os pais, e os adultos em geral, tanto escondem sob suas vestes -, o conhecimento e a investigação científica ou filosófica, que funcionam "sempre como substituto para a atividade sexual", não poderiam proporcionar a felicidade, já que o encontro com o sexual é traumático no seu ponto de partida (interdito do incesto, parricídio, Édipo). E a substituição não elide o trauma.

Entretanto, se a substituição é incapaz, a elaboração, no trabalho analítico, não cumpriria justamente esse papel? Não seria precisamente através de uma análise exitosa que o analisando se tornaria capaz de interpretar (elaborar) seus afetos, até atingir o núcleo dos seus traumas? Considerando a resposta afirmativa, é preciso dizer que esse processo não constituiria, ainda, uma felicidade, no sentido espinosano do termo. O que há em Espinosa, e não poderia haver em Freud, dada sua recusa de ir além do "real", é uma concepção do conhecimento de si mesmo como a maior alegria que pode existir. Para concluir nossas reflexóes, vejamos melhor essa distância que separa Freud de Espinosa, quanto aos efeitos psicoafetivos da açáo de conhecer.

\section{ConsideraÇốEs Finais}

Sabemos que Espinosa certamente dedicou quase toda a sua vida à filosofia. Alguns biógrafos e comentadores, todavia, desde as biografias de Lucas e Colerus (1678 e 1705, respectivamente), romantizando a figura do filósofo, preferiram desenhar a imagem de um Espinosa puro, absolutamente absorvido na tranquilidade de seu trabalho filosófico, distante das turbulentas paixóes humanas. Autor de uma obra de pensamento que buscou demonstrar 
um caminho possível para a felicidade humana neste mundo, Espinosa seria o mais sereno dos filósofos, assim como o mais virtuoso dos "ateus". Biografias mais recentes trataram de corrigir, na medida do possível, essa imagem de um Espinosa que seria praticamente "o Cristo dos filósofos".

O fato é que sabemos quase nada sobre sua vida amorosa. E, no entanto, as imagens românticas sobre Espinosa legadas pelos trabalhos de Lucas e Colerus conservam alguma verdade, se cogitarmos o oposto do que disseram: a imagem de um Espinosa que levasse uma vida agitada, "mundana" (no sentido pejorativo do termo), ardentemente passional etc., igualmente não faria justiça à biografia do filósofo da felicidade, ou seja, da verdadeira tranquilidade do ânimo. Essa felicidade, ele a chamou de amor intelectual de Deus, o afeto alegre mais forte que pode existir e que nasce imediatamente da compreensáo intelectual da imanência à Natureza de nosso corpo-mente singular.

Não precisamos, por conseguinte, de dados biográficos e empíricos para compreender que, em Espinosa, o conhecimento não só pode ser uma forma de amor, mas também a forma de amor supremo. Para isso, no entanto, é preciso que a experiência do pensamento seja o gozo e exercício desse Amor Dei Intellectuallis. Nesse caso, percorre-se um caminho que vai das ideias confusas, na paixão, à ideia adequada da essência singular do corpo próprio, na ação. Se esse caminho é árduo, como conclui Espinosa, ao final de sua Ética, é antes de mais nada porque ele exige e supóe uma transformação do desejo, à qual nem sempre somos dispostos.

O problema do desejo é central também na ética de Espinosa. O que desejamos, de fato? É a pergunta psicanalítica por excelência, como dizia Lacan. Em nosso esforço por viver da melhor maneira que nos é possível, o que convém desejar antes e acima de tudo? É a pergunta espinosana por excelência. A condição inicial de nossa experiência afetiva, entretanto, é a passionalidade. O que é uma paixão, em Espinosa? É, como já vimos, uma ideia confusa sobre o que se passa em nós, quando nosso corpo afeta ou é afetado por algo (pessoa ou coisa) exterior. Nesse tipo de relação afetiva - e estamos sempre, necessariamente, em relação com outras partes da Natureza -, a ideia que a mente é de seu corpo é uma ideia confusa, parcial, que diz mais sobre a constituição do corpo do que sobre a natureza do objeto externo (ESPINOSA, 2015a, p. 165). 
Se, nesse caso, a potência do corpo é aumentada, a alegria experimentada determina a afirmação do desejo desse objeto, ainda que apenas esta ou aquela parte do corpo seja afetada, em detrimento de outras partes ou da totalidade complexa do corpo. E, no limite, se nenhum afeto mais forte e contrário surgir, tendemos aos esforços de repetição do mesmo afeto, tendemos a desejar sempre e mais, sob as mesmas circunstâncias, o mesmo objeto, considerado como causa do aumento da potência. Tem-se então o amor pelo objeto, pois, em Espinosa, o amor é uma alegria acompanhada da ideia de uma coisa exterior como causa da alegria experimentada (ESPINOSA, 2015a, p. 343).

O grande problema é que dificilmente a passionalidade é vivida sem contrariedade. Alegrias passivas envolvem sempre algum grau ou tipo de tristeza. Em última análise, trata-se de um problema que concerne à finitude, seja dos corpos afetantes e afetados, seja dos objetos exteriores que também afetam e são afetados. Da finitude decorre, entre outras coisas, que os objetos de desejo e amor são perecíveis e inconstantes, e, portanto, pode-se sempre perdê-los, não adquiri-los ou perder o amor do objeto amado. Isso vale para todas as relaçôes amorosas passionais, mas talvez sobretudo para aquelas em que está envolvido o amor sexual, que, segundo Freud, como vimos, proporciona as mais intensas experiências de prazer. Freud, que jamais sancionou um "[...] viver até os limites sua vida sexual" (FREUD apud LANDMAN, 2007, p. 135), não disse outra coisa, quando escreveu, em $O$ mal-estar na civilizaçâo:

Afirmamos [anteriormente] que a descoberta de que o amor sexual (genital) proporcionava ao indivíduo as mais fortes vivências de satisfação, dandolhe realmente o protótipo de toda felicidade, deve tê-lo feito continuar a busca da satisfação vital no terreno das relaçóes sexuais, colocando o erotismo genital no centro da vida. Prosseguimos dizendo que assim ele se torna dependente, de maneira preocupante, de uma parte do mundo exterior, ou seja, do objeto amoroso escolhido, e fica exposto ao sofrimento máximo, quando é por este desprezado ou o perde graças à morte ou à infidelidade. Por causa disso, os sábios de todas as épocas desaconselharam enfaticamente esse caminho; não obstante, ele jamais deixou de atrair um grande número de seres humanos. (FREUD, 2010, p. 64).

Da finitude também decorre que as coisas desejadas e amadas podem ser objetos de disputas, gerando conflitos entre aqueles que os desejam sem poder possuí-los, ao mesmo tempo. Decorre, enfim, que podem deixar de ser causas de alegrias, se se altera a disposiçấo do corpo afetado ou do corpo afetante, de tal maneira que, por algum motivo, o que antes era causa de 
alegria agora já não é mais. Inconstância, mudança, conflito, insatisfação e frustração pertencem ao campo da finitude. A tristeza, desejo frustrado, é o fantasma que ronda sempre a condição dos seres finitos.

E, no entanto, a finitude nos define, porque assinala justamente nossa condição de modo, ou seja, de expressão certa e determinada da ação da Natureza. ${ }^{16}$ Escapar à nossa condição de seres finitos seria deixar de ser o que somos, isto é, seres essencialmente desejantes (ESPINOSA, 2015a, p. 339). O árduo caminho que vai da experiência da repetição das paixóes que envolvem tristeza à experiência da felicidade e liberdade exige e supóe, pois, uma transformação do desejo que nos leve a uma outra relação com nossa finitude e com os seres finitos externos. Sem abandonar o terreno da finitude - algo impossível -, mudamos, não o mundo, mas a nós mesmos, e essa mudança envolve toda uma transformação do desejo. Entretanto, como isso se dá? Aqui, somos remetidos novamente ao cerne da relação entre amor e conhecimento.

Vimos que todo afeto pressupóe necessariamente uma dimensão cognitiva, porque todo afeto é ao mesmo tempo uma afecção corporal e a ideia simultânea dessa afecção. Todo afeto é, portanto, uma forma de conhecimento. A paixão é um conhecimento confuso, parcial, dependente das relaçôes com a exterioridade. A ideia de que sou de mim mesmo, sob a paixão, é uma ideia que depende daquilo que não sou, a exterioridade. A paixão, nesse sentido, circunscreve o campo do negativo, em Espinosa. Todos os afetos de amor vivenciados nesse campo comportam os problemas da negatividade que apontamos acima. Mas, uma vez que não podemos abandonar absolutamente esse terreno, trata-se entấo de estabelecer uma nova relação com as paixóes. Essa nova relação, que o Tratado da Emenda do Intelecto nomeara novum institutum (ESPINOSA, 2015b, p. 27), permite, atravessando o fantasma das paixóes, alcançar estados afetivos ativos e duradouros.

Essa transformação ocorre, e só pode ocorrer, no campo mesmo dos afetos; não sem ele, não contra ele. A maneira como conheço a mim mesmo e a meus afetos é diferente, segundo eu esteja sob a condição das paixóes, ideia confusa sobre mim e a exterioridade; da razão, conhecimento do que é comum a mim, às outras partes e ao todo; ou da ciência intuitiva, conhecimento da

16 "É dita finita em seu gênero", escreve Espinosa, "[...] aquela coisa que pode ser delimitada por outra de mesma natureza. P. ex., um corpo é dito finito porque concebemos outro sempre maior. Assim, um pensamento é delimitado por outro pensamento. Porém, um corpo não é delimitado por um pensamento, nem um pensamento por um corpo." "Por modo", diz ele, "[...] entendo as afecçōes da substância, ou seja, aquilo que é em outro, pelo qual também é concebido.” (ESPINOSA, 2015a, p. 45). 
inserção necessária e imanente do corpo-mente singular à Natureza inteira. Neste último caso, e somente neste caso, o conhecimento da essência singular do corpo próprio se realiza como amor intelectual de Deus. Esse amor é intelectual - e é essa a novidade de Espinosa - porque é uma alegria que nasce do conhecimento intuitivo da causa prima de todas as coisas, Deus ou Natureza. Demonstrando esse conhecimento na Parte V da Ética, Espinosa realiza o que prometera no inacabado Tratado da Emenda, quando dissera que o sumo bem era o conhecimento de nossa uniáo com a Natureza inteira (ESPINOSA, 2015b, p. 33).

Sob a paixão, isto é, sob a parcialidade (ideia confusa que fala sobre mim mas com a condiçáo do outro que afeto e que me afeta) e a negatividade (tudo o que sei sobre mim depende do que não sou), encontro-me no isolamento, na fragmentação, na contingência e na ilusão da liberdade como livre arbítrio. Sob a ação, quando conheço e reconheço meu enraizamento necessário à "Nervura do real", para usar a famosa expressão de Marilena Chaui, ou à "Carne" do mundo, para falar como Merleau-Ponty; quando tenho a ideia verdadeira do todo, do Universo ao qual pertenço, náo como parte isolada, extrínseca, mas como modo imanente que exprime a ação eterna e infinita dos atributos de Deus, exprimindo-os de maneira certa e determinada; quando reconheço, enfim, meu próprio esforço de conhecer-me a partir do todo, da Natureza, exercendo assim o desejo de conhecer - que, aliás, tem início muito cedo em nossa vida afetiva, como Freud o mostrou - e compreendendo que esse esforço é um gesto contido no esforço ontologicamente determinado pelo qual sou levado a perseverar em minha existência -, sob a ação, enfim, é toda uma vida, é todo o meu ser que ganha sentido, um sentido marcado pela compreensão de minha presença e minhas açóes como modulaçóes imanentes à atividade eterna e infinita do ser absolutamente infinito. Esse sentido, em Espinosa, é o próprio gozo e exercício do amor intelectual de Deus, a alegria nascida da ideia verdadeira da essência singular do meu corpo próprio, sob a perspectiva da eternidade (sub specie aeternitatis).

No gozo e exercício desse amor, através do que Espinosa chama de ciência intuitiva, ou terceiro gênero de conhecimento, tornamo-nos capazes de conhecer e interpretar os próprios afetos, algo que a imaginação não pode fazer, porque nela o pensamento é determinado pela exterioridade, mas também a razão não o pode, posto que ela conhece apenas noçôes comuns, leis gerais da natureza que regem as relações entre as coisas, mas não essências singulares. É essa potência de pensar o corpo próprio e, em consequência, os próprios afetos, 
sob a perspectiva da eternidade, no exercício da ciência intuitiva, podendo assim interpretar os próprios afetos, transformando paixóes em açóes - é essa perspectiva que a psicanálise freudiana não pode oferecer, porque esse passo a mais - a compreensão de nossa união imanente com a Natureza inteira - o pensamento de Freud, por diversas razóes, recusou-se a dar.

Esse amor intelectual da Natureza é, para Espinosa, a maior alegria que pode existir, uma alegria que reabsorve e ressignifica todas as nossas paixôes, alegres ou tristes, passadas e presentes, tornando-nos capazes de moderá-las. Dentre os três grandes móbiles da vida humana - libido, honra e riquezas -, o amor sexual é geralmente o mais forte, e nisso reconhecemos o gesto freudiano de colocar a paixão sexual no centro da vida afetiva. Porém, não é porque ele não pode cumprir nosso desejo de felicidade - no caso no qual esse desejo emerge numa experiência afetiva transformadora ${ }^{17}$ - que, por assim dizer, nos desviamos dele, redirecionando a libido para interesses mais sublimes, como a arte, a religiáo ou, nos casos de Leonardo e Espinosa, o conhecimento, a pesquisa.

Em Espinosa, a transformação do desejo não é sublimação dos interesses sexuais em atividade de conhecimento. O que ocorre é uma transformação do próprio desejo, no exercício e gozo da atividade do amor intelectual da Natureza, pela qual reordenamos toda a experiência afetiva, unificando o desejo, antes disperso na diversidade dos bens exteriores perecíveis, em torno do conhecimento verdadeiro de nós mesmos, das coisas e da Natureza. A própria libido passa então por uma transformação radical, capaz de nos livrar das velhas paixóes que envolviam desprazer, tristeza, desejo frustrado e, no limite, a própria morte. Foi, de fato, uma experiência afetiva que levaria o meditante do prólogo do Tratado da Emenda do Intelecto à morte, o que determinou sua nova tomada de posição frente às paixôes, transformando seu desejo em desejo de uma "alegria contínua e suprema". Em outras palavras, a experiência narrada no início do Tratado é dramática, porque mostra um sujeito determinado pela alternativa entre a vida ou a morte:

Via-me, pois, às voltas com um sumo perigo e coagido a buscar um
remédio, ainda que incerto, com máximas forças, tal qual um doente
sofrendo de doença letal, que, quando prevê morte certa caso náo seja
administrado um remédio, é coagido a buscá-lo, ainda que incerto, com
máximas forças, já que nele situa-se toda a sua esperança. (ESPINOSA,
2015b, p. 31).

${ }^{17}$ Sobre esse tema, ver nosso trabalho Alegria e felicidade: a experiência do processo liberador em Espinosa. São Paulo: EDUSP, 2017. 
Todavia, é preciso, uma vez mais, insistir e deixar claro que não se trata de suprimir do campo da afetividade qualquer relaçáo com os objetos finitos que podem trazer desprazer e tristeza: trata-se de estabelecer com o mundo exterior uma relaçáo que nos torne capazes de gozar dos objetos de prazer sem as armadilhas e os perigos das paixóes, os quais podem chegar ao risco de morte. E se, na liberdade ou felicidade, uma tal relação é de fato possível, não é porque nos desviamos das paixóes (sobretudo o amor sexual), mas porque seguimos um caminho que é, ele mesmo, o gozo de um amor mais forte e contrário aos amores que antes causavam tristeza e contrariedade, e que agora podem justamente servir para o exercício mesmo do amor intelectual. $\mathrm{O}$ amor não é, por conseguinte, oposto ao conhecimento, mas antes se realiza plenamente nele.

Nas últimas palavras da Ética, as quais citamos na epígrafe, invertendo a fórmula de toda uma longa tradição que acreditava que a felicidade nascia da virtude, por sua vez filha do conhecimento, Espinosa afirma que não é porque coibimos as paixôes que somos felizes, mas porque somos felizes é que podemos coibir as paixóes:

[...] quanto mais a Mente goza deste Amor divino ou felicidade, tanto mais entende, isto é, tanto maior potência tem sobre os afetos, e tanto menos padece dos afetos que são maus. E assim, porque a mente goza deste Amor divino ou felicidade, ela tem o poder de coibir a lascívia [libidines]. E como a potência humana para coibir os afetos consiste no só intelecto, logo ninguém goza da felicidade porque coibiu os afetos, mas, ao contrário, o poder de coibir a lascívia [libidines] origina-se da própria felicidade. (ESPINOSA, 2015a, p. 579).

Definindo a felicidade ou liberdade como o próprio amor intelectual da Natureza, o pensamento espinosano desfaz a oposição entre conhecimento e afeto, fazendo do "grande conhecimento" (o conhecimento de si na imanência) um "grande amor". Aqui, o gesto espinosano não dá lugar à sublimação, porque não se deixa apreender pela substituição do gesto amoroso pela atividade cognitiva de conhecimento: ato de amor e ação de conhecimento são uma só e mesma coisa. Nesse caso, a ação de conhecer é a maior alegria que pode existir, porque é desprovida das possibilidades de tristeza ou frustração do desejo.

E, assim, o ser, antes cindido, dividido entre o desejo interno e as exigências do mundo externo, entre "princípio do prazer" e "princípio de realidade" - e era também este o grande conflito em Freud -, agora se 
unifica, se singulariza, alcança o sentido de existir, viver, amar e trabalhar (isto é, criar). Mas não era justamente esse o horizonte terapêutico e analítico da psicanálise? Em todo caso, esse horizonte de felicidade e liberdade é alcançável, em Espinosa, embora de modo algum seja um caminho fácil de ser trilhado. E, de fato, não poderia ser diferente, pois, como escreve o filósofo, ao final da Ética, "[...] tudo o que é notável é tão difícil quanto raro."

PAULA, M. F Love and knowledge: Freud and Spinoza. Trans/form/ação, Marília, v. 44, n. 4, p. 291-320, Out./Dez., 2021.

\begin{abstract}
In this article, a reflection is made on the relation between love and knowledge in Freud and Espinosa, taking as the nucleus of the analysis the theses of Freud in his famous essay on Leonardo da Vinci. It is tried to show that the Freudian oposition between love and knowledge, oposition that lets itself be captured in the concept of sublimation, does not have place in the thought of Espinosa. In the Spinoza's theory of the affects, such the oposition undoes; and it is above all through the concept of Amor Dei Intellectuallis, presented in Part V of his Ethics, that Spinoza reveals that instead of oposition, there is rather the full realization of the love as the action of the mind that knows itself in the heart of immanent Nature.
\end{abstract}

Keywords: Freud. Love. Knowledge. Spinoza. Sublimation.

\title{
REFERÊNCIAS
}

DA VINCI, L. Trattato della pittura. Milano: TEA, 1995.

ESPINOSA, B. de. Tratado Teológico-político. Trad. Diogo Pires Aurélio. São Paulo: Martins Fontes, 2003.

ESPINOSA, B. de. Tratado Político. Trad. Diogo Pires Aurélio. São Paulo: Martins Fontes, 2009 .

ESPINOSA, B. de. Ética. Trad. Grupo de Estudos Espinosanos. São Paulo: EDUSP, 2015a.

ESPINOSA, B. de. Tratado da emenda do intelecto. Trad. Cristiano N. de Resende. Campinas: UNICAMP, 2015b.

FREUD, S. Luto e Melancolia. In: FREUD, S. Ediçáo Standard Brasileiras das Obras

Completas de Sigmund Freud, v. XIV. Rio de Janeiro: Imago, 1917 [1915]/1974. 
FREUD, S. Carta de 28/6/1931 a Lothar Bickel. In: SOUZA, P. C. (org.). Sigmund Freud e o Gabinete do Dr. Lacan. São Paulo: Brasiliense, 1990.

FREUD, S. Obras psicológicas completas (Edição Standard - V. XI). Rio de Janeiro: Imago, 1996.

FREUD, S. Obras Completas, v. 18. São Paulo: Companhia das Letras, 2010.

FREUD, S. Obras Completas, v. 9. São Paulo: Companhia das Letras, 2013.

FREUD, S. Obras Completas, v. 17. São Paulo: Companhia das Letras, 2014.

FREUD, S. Obras Completas, v. 6. São Paulo: Companhia das Letras, 2016.

GAY, P. Freud: uma biografia para o nosso tempo. 2. ed. São Paulo: Companhia das Letras, 2012.

JUFFÉ, M. Sigmund Freud - Benedictus de Spinoza: correspondance (1676-1938). Paris: Gallimard, 2016.

LANDMAN, P. Freud. São Paulo: Estação Liberdade, 2007.

NASIO, J.-D. Um psicanalista no divá. Rio de Janeiro: Zahar, 2003.

PAULA, M. F. de. Alegria e felicidade: a experiência do processo liberador em Espinosa. São Paulo: EDUSP, 2017.

ROUDINESCO, E. Sigmund Freud na sua época e em nosso tempo. Rio de Janeiro: Zahar, 2016.

SOUZA, P. C. (org.). Sigmund Freud e o Gabinete do Dr. Lacan. São Paulo: Brasiliense, 1990.

Recebido: 07/7/2019

Aceito: $27 / 5 / 2020$ 
PAULA, M. F 